\title{
PENGARUH LIMBAH PECAHAN GENTENG SEBAGAI PENGGANTI AGREGAT KASAR PADA CAMPURAN MUTU BETON 16,9 MPa (K.200)
}

\author{
Asri Mulyadi ${ }^{1}$, Fachrul Rozi ${ }^{2)}$ \\ Program Studi Teknik Sipil Fakultas Teknik \\ Universitas Palembang \\ e-mail : asri_anang@yahoo.co.id
}

\begin{abstract}
ABSTRAK
Memakai material bahan limbah pecahan genteng sebagai pengganti agregat kasar pada campuran beton di Indonesia masih belum banyak dilakukan, tetapi sudah mulai digunakan antara lain untuk pengurukan, lapisan pondasi jalan dan lain-lain. Hal ini disebabkan karena bahan baku agregat kasar mudah didapat. Namun cepat atau lambat material akan semakin habis sehingga menyebabkan material dari tahun ketahun akan semakin mahal. Melihat dari uraian di atas maka disini perlu untuk melakukan pemanfaatan material limbah pecahan genteng sebagai pengganti agregat kasar. Pada penelitian ini beda uji dicetak dengan menggunakan kubus baja ukuran $15 \mathrm{~cm}$ x $15 \mathrm{~cm} \times 15 \mathrm{~cm}$, masing-masing umur perendaman yaitu 7 hari, 14 hari, 21 hari dan 28 hari dengan pengujian kuat tekan beton. Pada campuran mutu beton 16,9 MPa (K.200) tersebut dibuat berfariasi yaitu dengan menggunakan material limbah pecahan genteng sebagai pengganti agregat kasar $0 \%, 10 \%, 25 \%$ dan 50\%. Dari hasil evaluasi uji kuat tekan yaitu pada beton tanpa menggunakan material pengganti agregat kasar atau beton normal pada umur beton 28 hari didapat kuat tekan beton sebesar $157,93 \mathrm{~kg} / \mathrm{cm}^{2}$, pada material limbah pecahan genteng sebagai pengganti agregat kasar 10\% umur beton 28 hari didapat kuat tekan beton sebesar $173,73 \mathrm{~kg} / \mathrm{cm}^{2}$, pada material limbah pecahan genteng sebagai pengganti agregat kasar $25 \%$ umur beton 28 hari didapat kuat tekan beton sebesar $141,12 \mathrm{~kg} / \mathrm{cm}^{2}$ dan material limbah pecahan genteng sebagai pengganti agregat kasar $50 \%$ umur beton 28 hari didapat kuat tekan beton sebesar $133,81 \mathrm{~kg} / \mathrm{cm}^{2}$.
\end{abstract}

Kata Kunci : Kuat Tekan Beton, Agregat, Limbah Pecahan Genteng.

\section{PENDAHULUAN}

\subsection{Latar Belakang}

Dalam perkembangan dunia yang semakin maju dan serbah canggih, teknologi beton mempunyai potensi yang luas dalam bidang konstruksi. Hal ini menyebabkan beton banyak digunakan untuk konstruksi bangunan gedung, jalan, jembatan dermaga dan lain-lain. Banyaknya jumlah penggunaan beton dalam konstruksi tersebut mengakibatkan peningkatan kebutuhan material beton, sehingga memicu penambangan batuan sebagai salah satu bahan pembentuk beton secara besar-besaran yang menyebabkan turunnya jumlah sumber alam yang tersedia untuk keperluan pembetonan [1]. Memakai material bahan limbah pecahan genteng sebagai pengganti agregat kasar dalam campuran beton di Indonesia masih belum banyak dilakukan, tetapi sudah mulai digunakan antara lain untuk pengurukan, lapisan pondasi jalan dan lain-lain. Hal ini disebabkan karena bahan baku agregat kasar 
mudah didapat. Namun cepat atau lambat material akan semakin habis sehingga menyebabkan material dari tahun ketahun akan semakin mahal. Melihat dari uraian di atas maka disini perlu untuk melakukan pemanfaatan material limbah pecahan genteng sebagai pengganti agregat kasar.

\subsection{Tujuan Penelitian}

1. Membandingkan kuat tekan beton normal dengan beton memakai bahan limbah pecahan genteng sebagai pengganti agregat kasar.

2. Mengetahui pengaruh limbah pecahan genteng sebagai pengganti agregat kasar dengan variabel tertentu terhadap kuat tekan beton.

\subsection{Manfaat Penelitian}

Pemanfaatan limbah pecahan genteng sebagai pengganti agregat kasar pada campuran beton.

\subsection{Rumusan Masalah}

Permasalahan yang akan dibahas dalam penelitian ini adalah sebagai berikut:

1. Bagaimana pengaruh limbah pecahan genteng sebagai pengganti agregat kasar tersebut terhadap kuat tekan beton.

2. Bagaimana pengaruh perbandingan beberapa variabel campuran limbah pecahan genteng sebagai pengganti agregat kasar terhadap kuat tekan.

3. Didalam penelitian ini penulis membatasi ruang lingkup pekerjaan pengujian - pengujian bahan material dan benda uji kuat tekan di laboratorium.

\subsection{Batasan Masalah}

Penelitian dilakukan terhadap beton dengan membandingkan antara beton normal dengan beton yang menggunakan limbah pecahan genteng sebagai pengganti agregat kasar, perlakuan yang diambil pada penelitian ini sebanyak 4 perbandingan yaitu ;

1. Beton Normal
2. Beton dengan menggunakan limbah pecahan genteng sebagai pengganti agregat kasar sebesar $10 \%$.

3. Beton dengan menggunakan limbah pecahan genteng sebagai pengganti agregat kasar sebesar $25 \%$.

4. Beton dengan menggunakan limbah pecahan genteng sebagai pengganti agregat kasar sebesar $50 \%$.

\section{Tinjauan Pustaka}

\subsection{Pengertian Beton}

Beton didefinisikan sebagai bahan yang diperoleh dengan mencampurkan agregat halus (pasir), agregat kasar (kerikil), air dan semen portland atau bahan pengikat hidrolis lain yang sejenis, dengan atau tanpa bahan tambah lain [2]. Beton didefenisikan sebagai campuran antara semen portland atau semen hidrolik yang lain, agregat kasar, agregat halus dan air atau dengan bahan tambahan hingga membentuk massa padat [3]. Mutu beton yang digunakan untuk komponen stuktural minimal kuat tekannya adalah 14,5 $\mathrm{MPa}$ atau kurang lebih setara dengan mutu beton K-175 [4].

Beton adalah campuran yang terdiri dari agregat alam, seperti : kerikil, pasir atau batu pecah dengan bahan pengikat semen Portland, kemudian semen Portland dengan air membentuk pasta pengikat butiran - butiran agregat menjadi massa yang padat dan tidak larut dalam air [5].

Berdasarkan pengertian-pengertian di atas, dapat disimpulkan bahwa beton adalah suatu campuran yang terdiri dari semen, agregat halus, agregat kasar, air dan bahan tambahan dengan perbandingan tertentu yang kemudian diaduk dan dituang dalam cetakan hingga mengeras dan membatu sesuai dengan bentuk yang diinginkan.

\subsection{Bahan Dasar Pembentuk Beton}

Beton terutama terdiri dari tiga bahan, yaitu: semen, air dan agregat, jika diperlukan dibutuhkan bahan pembantu (admixture) untuk merubah sifat-sifat tertentu dari beton yang bersangkutan. Semen merupakan bahan campuran yang secara kimiawi aktif setelah berhubungan dengan air. 
Agregat tidak memainkan peranan dalam reaksi kimia tersebut, tetapi berfungsi sebagai bahan pengisi mineral yang dapat mencegah perubahan-perubahan volume beton setelah selesai pengadukan. Beton pada umumnya mengandung :

1) Rongga - rongga udara $1 \%$ - $2 \%$

2) Pasta semen ( semen + air ) $25 \%$ - $40 \%$

3) Agregat ( Kasar + halus ) $60 \%$ $70 \%$

\subsection{Rencana Campuran Beton}

Perencanaan campuran beton adalah suatu cara untuk menentukan perbandingan bahan-bahan campurannya sedemikian sehingga untuk keadaan tertentu dihasilkan beton dengan sifat - sifat yang diisyaratkan dan dengan harga ekonomis.

SK SNI T-15-1990-03 tentang tata cara rencana campuran beton normal mengemukakan persyaratan umum yang harus dipenuhi dalam hal perencanaan campuran adalah sebagai berikut:

1. Proporsi campuran beton harus menghasilkan beton yang memenuhi persyaratan:

a. Kekentalan yang memungkinkan pekerjaan beton (Penuangan / pemadatan dan perataan) dengan mudah dapat mengisi acuan dan menutup permukaan secara serba sama (homogen)

b. Keawetan

c. Kuat tekan

d. Ekonomis

2. Beton yang dibuat harus menggunakan bahan agregat normal tanpa bahan tambahan.

Dalam perencanaan beton harus dipenuhi persyaratan :

a. Perhitungan perencanaan campuran beton harus didasarkan pada data sifatsifat bahan yang akan dipergunakan dalam produksi beton.

b. Susunan campuran beton yang diperoleh dari perencanaan ini harus dibuktikan melalui campuran coba yang menunjukkan bahwa proporsi tersebut dapat memenuhi kekuatan beton yang diisyaratkan.

\section{Metodologi Penelitian}

\subsection{Persiapan Peralatan}

Penelitian ini dilaksanakan dilaboratorium uji bahan di Program Studi Teknik Sipil Fakultas Teknik Universitas Palembang, sebelum penelitian dilakukan perlu adanya persiapan peralatan dan bahan.

Peralatan yang digunakan berupa alat - alat untuk memeriksa agregat terdiri dari :

1) Timbangan dengan ketelitian 0,1 gram

2) Satu set saringan, untuk memeriksa agregat halus dan kasar.

3) Gelas ukur

4) Piknometer

5) Kerucut terpancung

6) Penumbuk

7) Pan aluminium

8) Pelat kaca

9) Cawan

10) Oven yang dilengkapi pengatur suhu

11) Density spoon

12) Mesin penggetar ayakan

13) Timbangan

14) Spatula

15) Tabung silinder

16) Jangka sorong

17) Kuas

18) Ember plastic

Alat pembuat benda uji :

1. Timbangan

2. Cawan

3. Sendok spesi

4. Cetakan beton dengan ukuran $15 \mathrm{~cm} \mathrm{x} 15$ $\mathrm{cm} \times 15 \mathrm{~cm}$.

5. Peralatan pengukur slump, berupa :

a) Kerucut dengan diameter bagian bawah $20 \mathrm{~cm}$, bagian atas $10 \mathrm{~cm}$, dan tinggi $30 \mathrm{~cm}$, bagian atas dan bawah cetakan terbuka.

b) Tongkat pemadat dengan diameter 16 $\mathrm{mm}$, panjang $60 \mathrm{~cm}$ ujung dibulatkan dan sebaiknya bahan tongkat terbuat dari baja atau tahan karat.

c) Plat logam dengan permukaan rata dan kedap air

d) Plat siku 
6. Peralatan pengukur berat volume yang berupa :
a) Wadah baja yang berbentuk silinder dengan alat pemegang.
b) Tongkat pemadat.
c) Mistar perata

\subsection{Persiapan bahan - bahan penelitian}

1) Semen Portland Padang type I

2) Agregat halus ( pasir )

3) Agregat kasar ( koral)

4) Limbah pecahan genteng.

Sebelum membeli bahan-bahan

tersebut, sebaiknya diperkirakan terlebih dahulu berapa jumlah yang dibutuhkan. Untuk pasir : harus diperhitungkan yang terbuang setelah pengayakan. Sebaiknya jumlah pasir dan koral dilebihkan, agar pemeriksaan agregat tidak terulang lagi, karena mengingat karakteristik agregat tidak akan sama untuk tiap pembelian. Semen sebaiknya dibeli pada waktu mendekat hari pengecoran, karena penyimpanan semen yang terlalu lama akan mengurangi mutu, jika penyimpanan yang kurang tepat dapat menyebabkan semen mengeras dan terjadi penggumpalan.

\subsection{Pemeriksaan Agregat}

Penggunaan agregat dalam beton mencapai $70 \%-75 \%$ dari seluruh volume massa padat beton. Untuk mencapai kekuatan beton yang baik yang sesuai dengan yang direncanakan, maka perlu adanya pemeriksaan agregat.

\subsubsection{Pemeriksaan Agregat Halus}

Adapun pemeriksaan yang akan dilakukan untuk agregat halus yaitu berat jenis dan penyerapan, berat isi gembur dan padat, kadar lumpur, kadar air dan analisa ayak.

\subsubsection{Agregat Kasar}

Adapun pemeriksaan yang dilakukan pada agregat kasar yaitu berat jenis dan penyerapan, berat isi gembur dan berat isi padat, kadar lumpur dan analisa ayak.

\subsection{Pemeriksaan limbah pecahan genteng}

Pada penelitian ini material pengganti agregat kasar yang digunakan adalah limbah pecahan genteng yang dipotong - potong dengan ukuran $2 \mathrm{~cm}$ sampai $3 \mathrm{~cm}$ dengan desain pengganti agregat kasar 10\%, 25\%, $50 \%$, dari berat agregat kasar.

\subsection{Perencanaan Campuran Beton}

Metode perencanaan campuran beton yang digunakan dalam penelitian ini dengan menggunakan campuran beton dengan mutu beton rencana 16,9 $\mathrm{MPa}$ (K.200).

Dengan langkah kerja sebagai berikut:

1. Menentukan karakteristik kuat tekan yang diisyaratkan diambil 16,9 $\mathrm{MPa}$ atau 200 $\mathrm{kg} / \mathrm{cm}^{2}$ pada umur 28 hari dengan jumlah cacat $5 \%$ dari banyak sample.

2. Menentukan deviasi standar ( $\mathrm{s}$ ) dengan melihat tabel.

3. Nilai tambah ( margin ) menggunakan rumus $=\mathrm{k} \times \mathrm{s}$

4. Menghitung kekuatan rata-rata yang akan dicapai dengan menjumlahkan hasil nomor $1+3$

5. Menetapkan jenis semen yang digunakan adalah semen Portland type I

6. Menetapkan jenis agregat yang dipakai adalah:

- Agregat Halus : alami

- Agregat Kasar : alami / batu pecah

7. Faktor air semen ditentukan dengan berpedoman pada grafik 1 dan 2 kemudian disesuaikan dengan type semen yang dipakai dan kekuatan tekan yang direncanakan pada umur 28 hari.

8. Faktor air semen maksimum dapat dilihat pada tabel yang disesuaikan dengan kondisi penggunaan beton tersebut.

9. Menentukan tinggi slump dengan menyesuaikan kegunaan dari beton tersebut untuk konstruksi

10. Ukuran kadar agregat ditentukan dari hasil analisa saringan dengan mengambil ukuran agregat maksimum lolos saringan 
11. Kadar air bebas dapat dilihat pada tabel disesuaikan dengan besarnya slump dan ukuran agregat maksimum

12. Kadar semen tiap $m$ beton dihitung dari perbandingan air dengan factor air semen ( no $11 /$ no 7 ) .

13. Kadar semen maksimum tidak ditentukan jadi dapat diabaikan

14. Kadar semen minimum ditetapkan 275 $\mathrm{kg} / \mathrm{m}^{3}$

15. Susunan besar butir agregat disesuaikan dengan analisa saringan yang ditentukan

16. Persentase agregat halus diperoleh dari perbandingan gabungan antara agregat halus dan kasar

17. Berat jenis agregat kering permukaan diperoleh dari perbandingan rata - rata berat jenis agregat halus dan kasar

18. Berat jenis beton diperoleh dari grafik degan jalan membuat grafik baru yang sesuai dengan nilai berat jenis gabungan

19. Kadar agregat gabungan $=$ berat jenis beton dikurangi jumlah kadar semen dan kadar air.

20. Kadar agregat halus $=$ persentase agregat halus ( 16 ) x kadar agregat gabungan ( no 19)

21. Kadar agregat kasar $=$ kadar agregat gabungan ( 19 ) dikurangi kadar agregat halus ( 20 )

Dari langkah no.1 sampai no.21, didapat susunan campuran beton teoritis untuk tiap $1 \mathrm{~m}^{3}$ yaitu diperlukan semen sebanyak (no.12), air (no.11), pasir (no.20), koral (no.21)

Dalam perhitungan yang telah dilakukan, agregat halus dan agregat kasar dalam keadaan jenuh kering permukaan (SSD) maka apabila material yang ada di lapangan tidak jenuh kering permukaan harus dilakukan koreksi terhadap kebutuhan bahannya.

\subsubsection{Pengujian Slump}

Adapun langkah pengerjaannya adalah sebagai berikut :

1. Kerucut terpancung dan pelat dibasahi dengan kain basah.
2. Letakkan kerucut terpancung di atas pelat.

3. Isilah kerucut terpancung sampai penuh dengan beton segar dalam 3 lapisan, setiap 25 kali tumbukkan secara merata. Pada pemadatan, tongkat harus tepat masuk sampai lapisan bagian bawah tiap lapisan.

4. Selesai pemadatan ratakan permukaan benda uji dengan tongkat, tunggu selama 30 detik dan dalam jangka waktu ini semua benda uji yang jatuh disekitar kerucut harus disingkirkan.

5. Kemudian angkat kerucut secara perlahanlahan ke atas secara tegak lurus.

6. Ukurlah slump yang terjadi dengan menentukan penurunan benda uji terhadap puncak kerucut terpancung.

Perhitungan : Besar Slump = Tinggi Penurunan Benda Uji

\subsubsection{Pengujian Berat Isi Beton}

Adapun langkah pengerjaannya adalah sebagai berikut :

1. Basahi takaran volume campuran beton segar dengan air.

2. Tuangkan campuran beton segar ke dalam takaran tersebut sampai penuh dalam 3 lapisan, tiap lapis berisi kira-kira $1 / 3$ isi takaran tersebut. Setiap lapis dipadatkan dengan 25 tumbukkan secara merata. Pada pemadatan, tongkat harus masuk sampai lapisan bagian bawah tiap-tiap lapis.

3. Bersihkan bibir takaran dari campuran beton yang menempel, kemudian timbang.

4. Buang campuran beton segar dari takaran kemudian dibersihkan.

5. Timbang takaran dalam keadaan kosong. Perhitungan :

Berat Beton Segar + Berat Takaran berisi Beton Segar - Berat Takaran (silinder)

Volume takaran $=$ Volume silinder

$$
\mathrm{V}=\frac{1}{4} \pi \cdot D^{2} \cdot t
$$

Berat isi BetonSegar $=$

$\frac{\text { Berat beton segar }(\mathrm{kg})}{\text { Volume takaran }(\text { silinder }) \mathrm{m}^{3}}$




\subsubsection{Pembuatan Benda Uji}

Adapun langkah pengerjaannya adalah sebagai berikut :

1. Menghitung proporsi bahan campuran sesuai dengan mix desain

2. Menyiapkan masing-masing bahan campuran sesuai berat proporsi

3. Masukkan semen dan agregat ke dalam bak aduk kemudian aduk hingga tercampur rata.

4. Masukkan air sedikit demi sedikit sambil terus diaduk sampai keseluruhan air yang telah dihitung habis.

5. Pengadukan dilakukan sampai adukan beton homogen.

\subsubsection{Perawatan Benda Uji}

Setelah beton mengeras atau beton tersebut berumur $1 \times 24$ jam, beton dibuka dari cetakan. Pada saat membuka cetakan usahakan tidak ada getaran yang dapat menganggu proses pengerasan dan pengikatan beton. Setelah beton dibuka dari cetakan kemudian beton tersebut direndamkan dalam air selama umur beton yang diperhitungkan. Perendaman ini bertujuan untuk membantu proses pengerasan beton tersebut. Pada proses perendaman berfungsi untuk mengisi rongga-rongga yang ada pada beton, air beraksi dengan semen sehingga tidak ada rongga / pori yang belum terisi benar oleh adukan maka reaksi dari semen dan air tersebut akan menutup pori tersebut. Dengan perendaman ini maka diharapkan kekuatan yang ditargetkan dapat dicapai. pada perendaman ini juga dijaga agar jangan sampai beton mengalami getaran / gangguan yang dapat menganggu pengerasan.

\subsubsection{Pengujian Kuat Tekan beton}

Setelah beton mengalami masa perendaman atau pemeliharaan, jika sudah mencapai umur yang direncanakan maka beton tersebut harus diangkat dari perendaman. Setelah itu kubus beton dikeringkan dari air kemudian ditimbang untuk mengetahui berat isi dari beton keras, kemudian setelah itu dilakukan pengujian kuat tekan beton dengan menggunakan mesin uji kuat tekan.

Pengujian kuat tekan dilakukan pada beton yang telah mencapai umur yang direncanakan. Pengujian ini dilakukan untuk mengetahui kekuatan yang dicapai beton tersebut pada umur tertentu apakah hasilnya sesuai dengan yang direncanakan sesuai dengan proporsi yang dicampurkan. Pengujian kuat tekan dilakukan sampai beton tersebut tidak mampu lagi memikul beban yang diberikan oleh mesin penguji kuat tekan. Jika sudah didapat hasil dari pengujian kuat tekan maka langkah selanjutnya tinggal menganalisis beberapa kuat tekan yang didapat dari proporsi yang direncanakan.

\section{Analisa dan Pembahasan}

\subsection{Pemeriksaan Agregat Halus dan Kasar}

Dari pemeriksaan yang telah dilakukan di laboratorium didapat data - data sebagai berikut :

1. Agregat Halus

\begin{tabular}{|l|l|l|}
\hline No & \multicolumn{1}{|c|}{ Uraian } & \multicolumn{1}{|c|}{ Keterangan } \\
\hline 1 & Berat isi gembur & $1,091 \mathrm{gr} / \mathrm{cm}^{3}$ \\
\hline 2 & Berat Isi Padat & $1,269 \mathrm{gr} / \mathrm{cm}^{3}$ \\
\hline 3 & Berat jenis SSD & 2,427 \\
\hline 4 & Berat jenis kering & 2,362 \\
\hline 5 & Penyerapan & $2,775 \%$ \\
\hline 6 & Kadar Lumpur & $0,807 \%$ \\
\hline 7 & Kadar Air & $7,13 \%$ \\
\hline 8 & Gradasi Butiran & Zona 4 \\
\hline 9 & Modulus Kehalusan & 3,861 \\
\hline
\end{tabular}

2. Agregat Kasar

\begin{tabular}{|l|l|l|}
\hline No & \multicolumn{1}{|c|}{ Uraian } & \multicolumn{1}{|c|}{ Keterangan } \\
\hline 1 & Berat isi gembur & $1,37 \mathrm{gr} / \mathrm{cm}^{3}$ \\
\hline 2 & Berat Isi Padat & $1,55 \mathrm{~kg} / \mathrm{cm}^{3}$ \\
\hline 3 & Berat jenis SSD & 2,377 \\
\hline 4 & Berat jenis kering & 2,326 \\
\hline 5 & Penyerapan & $2,154 \%$ \\
\hline 6 & Kadar Lumpur & $3,297 \%$ \\
\hline 7 & Kadar Air & $3,702 \%$ \\
\hline 8 & Modulus Kehalusan & 8,77 \\
\hline
\end{tabular}




\begin{tabular}{|c|c|c|c|c|c|}
\hline Uraian & $\begin{array}{l}\text { Semen } \\
\left(\mathrm{kg} / \mathrm{m}^{3}\right)\end{array}$ & $\left(\begin{array}{c}\text { Pasir } \\
\left(\mathrm{kg} / \mathrm{m}^{3}\right)\end{array}\right.$ & $\begin{array}{c}\text { Koral } \\
\left(\mathrm{kg} / \mathbf{m}^{3}\right)\end{array}$ & $\underset{\left(\mathrm{kg} / \mathbf{m}^{3}\right)}{\operatorname{Air}}$ & Total \\
\hline $\begin{array}{l}\text { Bahan campuran untuk } \\
1 \mathrm{~m}^{3} \text { beton }\end{array}$ & 352 & 731 & 1031 & 215 & 2.329 \\
\hline Kadar air (\%) & - & 7,131 & 1,069 & - & - \\
\hline Penyerapan agregat $(\%)$ & - & 2,775 & 1,715 & - & - \\
\hline Air bebas agregat (\%) & - & 4,356 & $-0,646$ & - & - \\
\hline $\begin{array}{l}\text { Air bebas } \times \text { bebas } \\
\text { agregat }(\mathrm{kg})\end{array}$ & - & 19,250 & $-8,125$ & - & - \\
\hline Total & 352 & 404,512 & $3.806,229$ & 215 & 2.329 \\
\hline
\end{tabular}

1. Perbandingan berat antara masing masing campuran $1 \mathrm{~m}^{3}$ beton sebelum dikoreksi dan setelah dikoreksi kadar airnya adalah :

$$
\begin{aligned}
& \text { Semen }=\frac{352}{352}=1 \\
& \text { Pasir } \quad=\frac{731}{352}=2,08 \\
& \text { Kerikil } \quad=\frac{1031}{352}=2,93 \\
& \text { Air } \quad=\frac{215}{352}=0,61
\end{aligned}
$$

2. Komposisi campuran untuk setiap zak semen adalah :

$$
\begin{array}{ll}
1 \text { zak semen } & =50 \mathrm{~kg} \\
\text { Pasir }=2,08 \times 50 & =104 \mathrm{~kg} / \mathrm{m}^{3} \\
\text { Kerikil }=2,93 \times 50 & =146,5 \mathrm{~kg} / \mathrm{m}^{3} \\
\text { Air }=0,61 \times 50 & =30,5 \mathrm{lt} / \mathrm{m}^{3}
\end{array}
$$

3. Komposisi campuran beton untuk 12 kubus beton dalam satuan berat adalah : Ukuran kubus $=15 \mathrm{~cm} \mathrm{x} 15 \mathrm{~cm} \times 15$ $\mathrm{cm}$

$$
\begin{aligned}
& \text { Volume kubus }=\left(0,003375 \mathrm{~m}^{3}\right) \times 12 \\
& =0,0405 \mathrm{~m}^{3} \\
& \text { Semen }=0,0405 \times 352=14,256 \mathrm{~kg} \\
& \text { Air } \quad=0,0405 \times 215=8,708 \mathrm{~kg} \\
& \text { Pasir }=0,0405 \times 731=29,606 \mathrm{~kg} \\
& \text { Kerikil }=0,0405 \times 1031=41,756 \mathrm{~kg} \\
& \text { Total } \\
& =94,326 \mathrm{~kg}
\end{aligned}
$$

Pecahan Genteng $10 \%$

$=0,10 \times 41,756 \mathrm{~kg}=4,176 \mathrm{~kg}$

Pecahan Genteng $25 \%$

$=0,25 \times 41,756 \mathrm{~kg}=10,439 \mathrm{~kg}$

Pecahan Genteng $50 \%$

$=0,50 \times 41,756 \mathrm{~kg} \quad=20,878 \mathrm{~kg}$

\subsection{Hasil pengujian slump beton}

Adapun hasil pengujian slump beton dapat dilihat pada tabel berikut :

\begin{tabular}{|c|c|}
\hline Beton & Nilai slump $(\mathrm{cm})$ \\
\hline Normal & 9,5 \\
\hline $\begin{array}{c}\text { Pengganti Agregat } \\
\text { Kasar 10\% }\end{array}$ & 8,7 \\
\hline $\begin{array}{c}\text { Pengganti Agregat } \\
\text { Kasar 25\% }\end{array}$ & 7,2 \\
\hline $\begin{array}{c}\text { Pengganti Agregat } \\
\text { Kasar 50\% }\end{array}$ & 6,5 \\
\hline
\end{tabular}

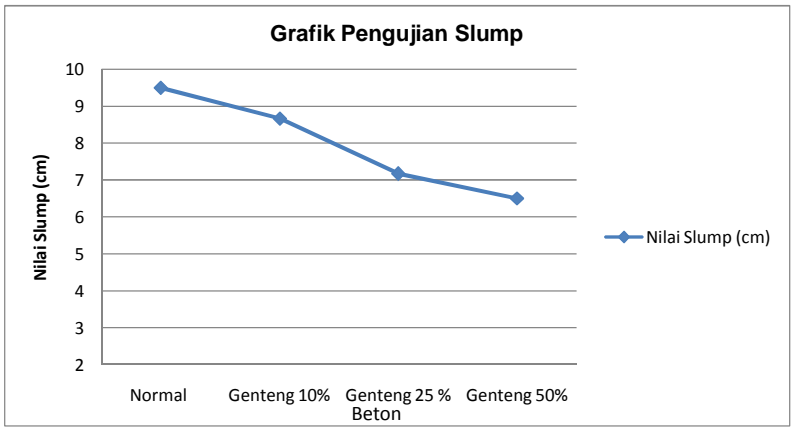

Berdasarkan grafik tersebut dapat diketahui bahwa slump yang dicapai mulai dari beton normal, beton dengan material pecahan genteng sebagai bahan pengganti agregat kasar $10 \%, 25 \%, 50 \%$ masih memenuhi slump yang disyaratkan antara $60-100 \mathrm{~mm}$. 


\subsection{Hasil Pengujian Kuat Tekan}

Rekapitulasi Evaluasi Hasil Uji

Kuat Tekan Beton dengan material pengganti agregat kasar 0\%, 10\%, 25\% dan $50 \%$ pada umur $7,14,21$ dan 28 hari

\begin{tabular}{|c|c|c|c|c|}
\hline \multirow{2}{*}{$\begin{array}{c}\text { Perlakuan Beton } \\
\text { K.200 }\end{array}$} & \multicolumn{4}{|c|}{ Kuat Tekan $\left(\mathrm{Kg} / \mathrm{Cm}^{2}\right)$} \\
\hline & $\begin{array}{l}\text { Umur } \\
\text { Beton }\end{array}$ & $\begin{array}{l}\text { Umur } \\
\text { Beton }\end{array}$ & $\begin{array}{l}\text { Umur } \\
\text { Beton }\end{array}$ & $\begin{array}{l}\text { Umur } \\
\text { Beton } \\
28 \text { Hari }\end{array}$ \\
\hline Beton Normal & 61,50 & 113,08 & 150,87 & 157,93 \\
\hline $\begin{array}{l}\text { Material Pengganti } \\
\text { Agregat Kasar } 10 \%\end{array}$ & 98,85 & 118,47 & 119,12 & 173,73 \\
\hline $\begin{array}{l}\text { Material Pengganti } \\
\text { Agregat Kasar } 25 \%\end{array}$ & 89,30 & 118,43 & 126,26 & 141,12 \\
\hline $\begin{array}{l}\text { Material Pengganti } \\
\text { Agregat Kasar 50\% }\end{array}$ & 85,68 & 102,63 & 132,97 & 133,81 \\
\hline
\end{tabular}

Sumber : Hasil uji Laboratorium

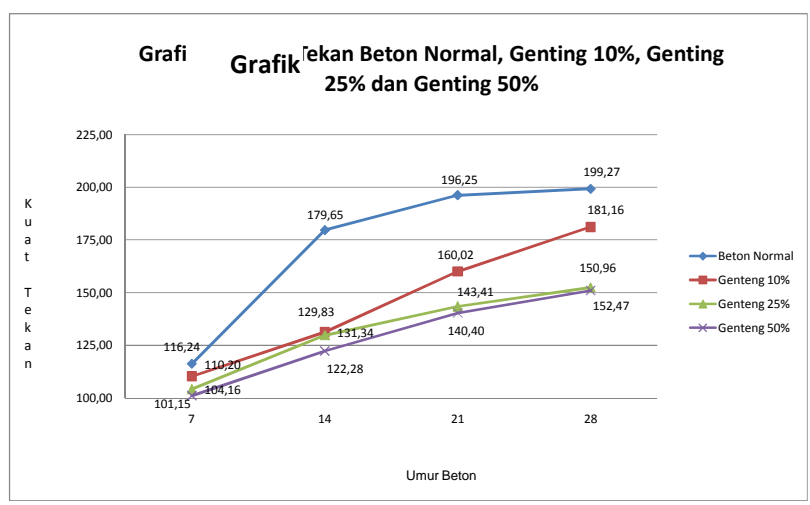

\section{Kesimpulan}

Dari hasil penelitian yang telah dilaksanakan dan dari hasil yang telah dicapai, penulis dapat menarik kesimpulan sebagai berikut :

$>$ Nilai evaluasi kuat tekan yang dicapai oleh beton tanpa menggunakan material pengganti agregat kasar atau beton normal pada umur 28 hari didapat kuat tekan $157,93 \mathrm{~kg} / \mathrm{cm}^{2}$.

$>$ Nilai evaluasi kuat tekan yang dicapai oleh beton dengan menggunakan limbah pecahan genteng atau material pengganti agregat kasar $10 \%$ kuat tekan pada umur 28 hari didapat $173,73 \mathrm{~kg} / \mathrm{cm}^{2}$.

$>$ Nilai evaluasi kuat tekan yang dicapai oleh beton dengan menggunakan limbah pecahan genteng atau material pengganti agregat kasar $25 \%$ kuat tekan pada umur 28 hari didapat $141,12 \mathrm{~kg} / \mathrm{cm}^{2}$.

$>$ Nilai evaluasi kuat tekan yang dicapai oleh beton dengan menggunakan limbah pecahan genteng atau material pengganti agregat kasar $50 \%$ kuat tekan pada umur 28 hari didapat $133,81 \mathrm{~kg} / \mathrm{cm}^{2}$.

\subsection{Saran}

Setelah melakukan penelitian ini, penulis mempunyai saran yang mungkin dapat berguna bagi penelitian selanjutnya, yaitu :

$>$ Perlu dilakukan penelitian lanjutan dengan variasi persentase pengganti agregat kasar yang berbeda dan pengujian umur beton lebih dari 28 hari.

$>$ Perhatikan umur rendaman benda uji, karena sangat berpengaruh pada waktu pengujian.

\section{Dafatar Pustaka}

[1] Teknik Sipil UNY. Suharwanto. 2005. The Mechanical Behavior Of Recycled Aggregate

[2] Departemen Pekerjaan Umum. 1982. Peraturan Umum Bahan Bangunan Indonesia (PUBI). Bandung: Departemen Pekerjaan Umum

[3] Standar Nasional Indonesia (SK SNI T-151991-03) Tata cara perhitungan struktur beton untuk bangunan gedung. Bandung: Departemen Pekerjaan Umum

[4] Dipohusodo, I. 1999. Struktur Beton Bertulang Berdasarkan SK SNI-T-151991-03 Departemen Pekerjaan Umum RI. PT Gramedia Pustaka Utama : Jakarta.

[5] Teknologi Bahan II, PEDC, Bandung 1987

[6] Dep. Pekerjaan umum , Badan Penelitian dan Pengembangan PU, tata cara Pembuatan Rencana Campuran Beton Normal SKSNI , T - 15 - $1990-03$ Yayasan LPMB, Bandung , 1990. 